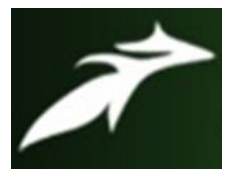

Tanuja Pragada et al, International Journal of Advances in Agricultural Science and Technology,

Vol.7 Issue.11, November-2020, pg. 38-44

ISSN: 2348-1358

Impact Factor: 6.057

NAAS Rating: 3.77

\title{
SOCIO ECONOMIC CHARACTERISTICS OF THE ADOPTERS OF SPRINKLER IRRIGATION SYSTEM OF SRIKAKULAM DISTRICT OF ANDHRA PRADESH
}

\author{
Tanuja Pragada ${ }^{1}$; Asst. Professor (Dr.) Sayed.H.Mazhar ${ }^{2}$ \\ M.Sc. Scholar ${ }^{1}$, pragadatanuja253@ gmail.com \\ Department of Agricultural Extension \& Communication \\ Sam Higginbottom University of Agriculture, Technology \& Sciences, Prayagraj \\ DOI: 10.47856/ijaast.2020.v07i11.006
}

\begin{abstract}
The present study was undertaken in Srikakulam district Andhra Pradesh purposively. Only few of the farmers have sprinkler irrigation system in different crops in this district. Six villages were selected purposively from this district on the basis of higher number of farmers having sprinkler irrigation system. Thus, total 6 villages were selected. From each selected village, 10 farmers were selected randomly making a sample of 60 beneficiaries and 60 non beneficiaries' total 120 respondents. $23.33 \%$ of beneficiaries possess 2 farm material and (28.33\%) of non-beneficiaries possess 2 farm materials. Half (50\%) of beneficiaries source of irrigation is other type except bore well, river, canal and pond and (33.33\%) of non-beneficiaries source of irrigation is bore well. 33\% of beneficiaries have medium level of livestock category and (48.33\%) of non-beneficiaries has belongs to livestock category.

Keywords: Adopter, Beneficiary, Socio- Economic, Non-beneficiary, Sprinkler irrigation.
\end{abstract}

\section{Introduction:}

Agriculture is the back bone of the Indian economy. India has over 10 cores population and around $70 \%$ of its population is engaged in agriculture and allied activities. The surge in gross domestic production (GDP) during 2005-06 is largely on account of agriculture, which grows at 6.30 per cent (Anon. 2007). Irrigation is the backbone of agriculture, irrespective of size of holding. Tremendous efforts have been made in the past to increase the irrigated area through construction of large number of surface irrigation projects and through ground water resources since the first five year plan. As a result, the irrigated area has increased by almost $250 \%$ form what it was in 1950-51. At present, out of 139.9 $\mathrm{M}$ ha of net sown area, about 45.2\% (63.2 Mha) is irrigated and remaining 54.8\% area is sown under rainfed condition (Moa, 2018-19).

The irrigation development in Srikakulam, a north coastal district of Andhra Pradesh is mainly dependent on tanks. But during the past five decades the district recorded a negative growth rate of irrigation. This necessitated a systematic study to be conducted on irrigation water 


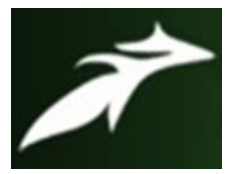

Tanuja Pragada et al, International Journal of Advances in Agricultural Science and Technology, Vol.7 Issue.11, November-2020, pg. 38-44

ISSN: 2348-1358

Impact Factor: 6.057

NAAS Rating: 3.77

requirements considering all principal crops grown in the district. The daily needs for food is increasing and supply decreasing. In order fulfil their demand agriculture production should be increased. This can only be possible through adopting modern irrigation technology which can be eligible for utilizing surface water in the area. Sprinkler system of irrigation is best alternative for the farmers which not increase the productivity of the crop but also save water at optimum level. The puplization of sprinkler irrigation technology among the farmers is increasing day by day. The district of srikakulam is $12^{\text {th }}$ ranked in sprinkler irrigation set used by farmers in the state of Andhra Pradesh.

\section{Methodology:}

The present study was confined to ex-post facto research design and present study was conducted in the Srikakulam district of Andhra Pradesh. Among all the 38 Mandals of Srikakulam district two was selected those having the largest irrigated area under sprinkler irrigation system. Therefore, these two Mandals were selected purposively for the study. A list of villages those having sprinkler irrigation system were prepared. From this list 6 villages from each Mandal were selected randomly, thus total 12 villages were selected randomly. After selecting villages a list of farmers, who had adopters of sprinkler system, were obtained from concerned GSFC / Banks/Irrigation Department of District and Mandals. Form each selected village, 10 farmers were selected randomly appropriate statistical tools. is used to measure the results by making a sample of 120 respondents.

\section{Results:}

Table no 1. Variables and their frequency and percentages.

\begin{tabular}{|c|l|c|l|c|c|}
\hline Variable & Category & \multicolumn{2}{l|}{ Beneficiaries } & \multicolumn{2}{l|}{ Non beneficiaries } \\
\hline \multirow{5}{*}{ 1.Age } & Frequency & $\begin{array}{l}\text { Percent } \\
(\boldsymbol{\%})\end{array}$ & Frequency & Percent (\%) \\
\hline & Young (18-35) & 10 & 16.66 & 12 & 20 \\
\cline { 2 - 6 } & Middle (36-50) & 38 & 63.33 & 42 & 70 \\
\cline { 2 - 6 } & Old above 50 years & 12 & 20 & 6 & 10 \\
\hline \multirow{4}{*}{ 2. Education } & Illiterate & 32 & 53.33 & 36 & 60 \\
\cline { 2 - 6 } & Primary school & 12 & 20.00 & 7 & 11.66 \\
\cline { 2 - 6 } & Upper primary & 4 & 6.66 & 8 & 13.33 \\
\cline { 2 - 6 } & High school & 5 & 8.33 & 5 & 8.33 \\
\hline
\end{tabular}




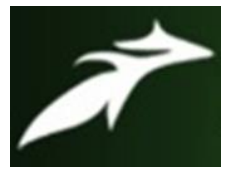

Tanuja Pragada et al, International Journal of Advances in Agricultural Science and Technology,

Vol.7 Issue.11, November-2020, pg. 38-44

ISSN: 2348-1358

Impact Factor: 6.057

NAAS Rating: 3.77

\begin{tabular}{|c|c|c|c|c|c|}
\hline & Intermediate & 5 & 8.33 & 3 & 5 \\
\hline & Under graduation & 2 & 3.33 & 1 & 1.66 \\
\hline & Post-graduation & 0 & 0 & 0 & 0 \\
\hline \multirow{2}{*}{ 3.Occupation } & Main (Agriculture) & 60 & 100 & 60 & 100 \\
\hline & Subsidiary & - & - & - & - \\
\hline \multirow{4}{*}{$\begin{array}{l}\text { 4. Type of } \\
\text { house }\end{array}$} & Hut & 7 & 11.66 & 13 & 21.66 \\
\hline & Kaccha & 6 & 10.00 & 10 & 16.66 \\
\hline & Semi cemented & 23 & 38.33 & 17 & 28.33 \\
\hline & Cemented & 24 & 40.00 & 19 & 33.33 \\
\hline \multirow{4}{*}{ 5.Land holding } & $>2.5$ acre & 13 & 21.66 & 23 & 38.3 \\
\hline & 2.6-5.0 acre & 38 & 63.33 & 34 & 56.66 \\
\hline & $5.1-10$ acre & 7 & 11.66 & 3 & 5.00 \\
\hline & Above 10 acres & 2 & 3.33 & 0 & 0 \\
\hline \multirow{4}{*}{ 6. Income } & Up to Rs. 3000 & 36 & 60.00 & 30 & 50.00 \\
\hline & \begin{tabular}{|l|} 
Rs. 3000-6000 \\
\end{tabular} & 11 & 11 & 21 & 35.00 \\
\hline & \begin{tabular}{|l|} 
Rs. 6000-9000 \\
\end{tabular} & 9 & 9 & 7 & 11.66 \\
\hline & Above Rs. 9000 & 4 & 4 & 2 & 3.33 \\
\hline \multirow[t]{4}{*}{ 7. Religion } & Hindu & 55 & 91.66 & 46 & 76.66 \\
\hline & Muslim & 0 & 0 & 0 & 0 \\
\hline & Christian & 5 & 8.33 & 14 & 23.3 \\
\hline & Others & 0 & 0 & 0 & 0 \\
\hline \multirow{4}{*}{ 8.Caste } & ST & 44 & 73.33 & 40 & 66.66 \\
\hline & SC & 3 & 5 & 17 & 28.33 \\
\hline & OBC & 14 & 23.33 & 3 & 5 \\
\hline & \begin{tabular}{|l|} 
Others \\
\end{tabular} & 0 & 0 & 0 & 0 \\
\hline \multirow{2}{*}{ 9.Family } & Nuclear & 36 & 60 & 37 & 61.66 \\
\hline & Joint & 24 & 40.00 & 23 & 38.33 \\
\hline \multirow{3}{*}{$\begin{array}{l}\text { 10.Material } \\
\text { possession }\end{array}$} & None & 9 & 15.00 & 12 & 20.00 \\
\hline & $\begin{array}{l}\text { One farm materials } \\
\text { (Bullock/ Buffalo/ } \\
\text { Bicycle/ Furniture) }\end{array}$ & 10 & 16.66 & 7 & 11.66 \\
\hline & $\begin{array}{l}2 \text { Farm material } \\
\text { (Radio / Bullock } \\
\text { cart/ T.V) }\end{array}$ & 14 & 23.33 & 17 & 28.33 \\
\hline
\end{tabular}




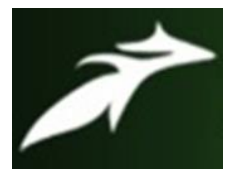

Tanuja Pragada et al, International Journal of Advances in Agricultural Science and Technology,

Vol.7 Issue.11, November-2020, pg. 38-44

ISSN: 2348-1358

Impact Factor: 6.057

NAAS Rating: 3.77

\begin{tabular}{|c|c|c|c|c|c|}
\hline & $\begin{array}{l}\text { 3-4 Farm material } \\
\text { (improved farm } \\
\text { implements / } \\
\text { electricity) }\end{array}$ & 10 & 16.66 & 12 & 20.00 \\
\hline & $\begin{array}{l}\text { 5-10 Farm material } \\
\text { (Goober gas/ pump } \\
\text { sets/ Motor bike) }\end{array}$ & 9 & 15 & 6 & 10.00 \\
\hline & $\begin{array}{l}\text { More than } 10 \text { farm } \\
\text { material (Tractor / } \\
\text { Automobile }\end{array}$ & 8 & 13.33 & 4 & 6.66 \\
\hline \multirow{5}{*}{$\begin{array}{c}\text { 11.Source of } \\
\text { irrigation }\end{array}$} & Bore well & 19 & 31.66 & 20 & 33.33 \\
\hline & River & 10 & 16.66 & 8 & 13.33 \\
\hline & Canal & 8 & 13.33 & 5 & 8.33 \\
\hline & Pond & 20 & 33.00 & 23 & 38.33 \\
\hline & Others & 30 & 50.00 & 4 & 6.66 \\
\hline \multirow{6}{*}{$\begin{array}{c}\text { 12.Livestock } \\
\text { possession }\end{array}$} & Buffaloes & 8 & 13.33 & 13 & 21.66 \\
\hline & Cows & 21 & 35 & 29 & 48.33 \\
\hline & Bullocks & 20 & 33.33 & 17 & 28.33 \\
\hline & Sheep / goats & 4 & 6.66 & 3 & 5 \\
\hline & Poultry birds & 2 & 3.33 & 1 & 1.66 \\
\hline & Others & 5 & 8.33 & 6 & 10.00 \\
\hline Total & & 60 & 100 & 60 & 100 \\
\hline
\end{tabular}

From the table no 1 . reveals that most $(63.33 \%)$ of the beneficiaries belongs to middle aged i.e., 36-50 years. Also, Majority (70\%) of the non-beneficiaries belonged to the middle age group. Most $(53.33 \%)$ of beneficiaries were Illiterate and $(60 \%)$ of non-beneficiaries are also Illeterate. Majority (100\%) of beneficiaries are solely dependent on farming for income while, (100\%) of non-beneficiaries are dependent on farming. Majority (63.33\%) of beneficiaries land holding is 2.6-5.0 Acres and (56.6\%) of non-beneficiaries land holding is 2.6-5.0 acres. Majority (91.66\%) of beneficiaries belongs to Hindu religion and (76.66\%) of non-beneficiaries belongs to Hindu religion. Majority (60\%) of beneficiaries belongs to Nuclear family type and (61.66\%) of non-beneficiaries belongs to nuclear type of family. Majority $(23.33 \%)$ of beneficiaries possess 2 farm material and (28.33\%) of non-beneficiaries possess 2 farm material. Majority (50\%) of 


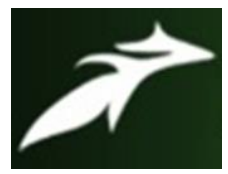

Tanuja Pragada et al, International Journal of Advances in Agricultural Science and Technology, Vol.7 Issue.11, November-2020, pg. 38-44

ISSN: 2348-1358

Impact Factor: 6.057

NAAS Rating: 3.77

beneficiaries source of irrigation is other type except borewell, river, canal and pond and (33.33\%) of non-beneficiaries source of irrigation is borewell. Most (53.33\%) of beneficiaries has medium level of contact with extension person and $(30 \%)$ of non-beneficiaries have low level of contact with extension person. Most (33\%) of beneficiaries has medium level of livestock category and $(48.33 \%)$ of non-beneficiaries has belongs to livestock category. On the basis of the type of house the beneficiaries and non-beneficiaries were classified into four categories i.e., hut kacha, semi cemented and cemented. A perusal of data presented in table 1 revealed that 11.66 per cent of the house of the beneficiaries and 21.66 per cent of non-beneficiaries belong to Hut, 10.00 per cent of beneficiaries and 16.66 per cent of non-beneficiaries belong to kaccha, 38.33 per cent of beneficiaries and 28.33 per cent of non-beneficiaries belong to semi cemented while as 40.00 per cent of beneficiaries and 33.33 per cent of non-beneficiaries at cemented.

On the basis of the size of land holding the beneficiaries and non-beneficiaries were classified into four categories i.e., marginal farmers > 2.5acre, 2.6-5.0 acre, 5.1 -10 acre and Above 10 acres. A perusal of data presented in table 3 reveals that majority of the 21.66 per cent of beneficiaries and 38.33 per cent of non-beneficiaries were placed under $>2.5$ acre, 63.33 per cent of beneficiaries and 56.66 were placed under 2.6-5.0 acre, 11.66 per cent of beneficiaries and 5.00 per cent of non-beneficiaries were placed under 5.1 -10 acre where as the 3.33 per cent of beneficiaries were placed under above 10 acre. None of the non-beneficiaries were place under above 10 acres. The findings collected for their annual income revealed that the income of the beneficiaries and non-beneficiaries led to have significant influence on socio-economic status of the beneficiaries and non-beneficiaries. It is clear that the income is the most important factor in socio-economic condition of beneficiaries and non-beneficiaries and it plays key role in adoption of any new practices. It can be inferred from Table .1 that 60.00 per cent of beneficiaries and 50.00 per cent of non-beneficiaries were from below poverty line having income upto Rs. 3000 per month, 11.00 per cent of beneficiaries and 35.00 per cent of non-beneficiaries having medium income Rs. 3000-6000 per month, 9.00 per cent of beneficiaries 11.66 per cent of non-beneficiaries have high income Rs. $6000-90000$ while as 4.00 per cent of beneficiaries and 3.33 per cent of non-beneficiaries having highest income Rs. $6000-9000$ per month. It can be inferred from the Table 2 that 23.33 per cent of beneficiaries and 28.33 per cent of non-beneficiaries were used 2 Farm material (Radio / Bullock cart/ T.V), 16.66 per cent of beneficiaries 20.00 per cent of none beneficiaries were obtained from 3-4 Farm material (improved farm implements / electricity), while as 15.00 per cent beneficiaries and 20.00 per cent non beneficiaries were obtained from One farm materials (Bullock/ Buffalo/ Bicycle/ Furniture). It can be inferred from the Table 2 and that 31.66 per cent of beneficiaries and 33.33 per cent of non-beneficiaries used bore well, 16.66 per cent beneficiaries and 13.33 per cent of none 


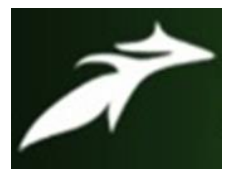

Tanuja Pragada et al, International Journal of Advances in Agricultural Science and Technology, Vol.7 Issue.11, November-2020, pg. 38-44

ISSN: 2348-1358

Impact Factor: 6.057

NAAS Rating: 3.77

beneficiaries used from river, 13.33 per cent of beneficiaries 8.33 per cent of non-beneficiaries used from canal, 33.00 per cent of beneficiaries and 38.33 per cent of non-beneficiaries obtain in pond while as 50.00 per cent of beneficiaries and 6.66 per cent of non-beneficiaries were used for, other resources. It can be inferred from Table 1. It could be observed that 13.33 per cent beneficiaries and 21.66 non beneficiaries had buffalo. 35.00 per cent beneficiaries and 48.33 non beneficiaries had cows. 33.33 per cent of beneficiaries and 28.33 per cent of non-beneficiaries had bullocks. 6.66per cent of beneficiaries and 5 per cent of none beneficiaries had sheep / goats. 3.33 per cent of beneficiaries and 1.66 non beneficiaries had poultry birds while as 8.33 per cent of beneficiaries and 10.00 non beneficiaries had others animals. Similar finding was also found by kumar et al., (2012), Ahire and Khalache et al., (2011), Taley et. al., (2005).

\section{Conclusion:}

The major number people are farmers and majority of farmers are belonged to cemented and semi cemented house type from respective six villages. farmers had medium size of land holding. These farmers had income in between Rs.3000 to Rs.6000 per month and used river and pond as an irrigation sources. These farmers mostly using television for Agri programs, news, entrainment and advertisement. These farmers possessed good knowledge about sprinkler irrigation system. Majority of the farmers were found to have medium level of adoption of sprinkler irrigation system.

Education, occupation, family caste, religion and source of irrigation had positive and significant association observed with their extent of knowledge and adoption of sprinkler irrigation system. The variables viz. land holding, annual income of the farmers were negatively and significantly associated with their extent of knowledge and adoption of sprinkler irrigation system.

\section{References:}

[1]. Ahire and Khalache (2007) Knowledge level of groundnut growers (Phule Prgati) from Hatkangale Tahsil of Kolhapur, India. Internet J. Agric. Sci. Vol.3 No.2 June, 2007: 286-289.

[2]. Akshaya Ghintala and Krishna Singh (2013) Knowledge and adoption of sprinkler irrigation system by the farmers of banaskantha district of north Gujarat. Ind. J. Extn. Educ. \& R.D. 21: 26-29, 2013.

[3]. Barse, K.N; Gohad, V.V and Lunge, M R. (2010) adoption of drip irrigation system by orange growers in Amravati Taluka. Agriculture update: 2010. 5(3/4):346-348.ref. 


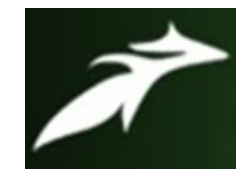

Tanuja Pragada et al, International Journal of Advances in Agricultural Science and Technology,

Vol.7 Issue.11, November-2020, pg. 38-44

ISSN: 2348-1358

Impact Factor: 6.057

NAAS Rating: 3.77

[4]. Deen, K .K; Nanh. B ; Alshalak, M.B and Abdul-Alaziz, A.(2012) the factors effecting the adoption of sprinkler irrigation technique for underground irrigated wheat in the first and second agricultural stability zone in two provinces of Aleppo and ladle. Arab university journal of agricultural sciences: 2012. 20(1):45-57.8 refs.

[5]. Kumar. D; Sharma.D; Y.S. Jadoun and P. Bhadauria (2012) a study on the extent of adoption of sprinkler irrigation system by the farmers in jhunjhunu district of Rajasthan. Agric. Sci. Digest 32 (1): 33 - 37, 2012.

[6]. Taley, S.M and Patode, R.S (2005) on farm enhanced water use efficiency and productivity attributed to adoption of micro irrigation in India transactions of the $19^{\text {th }}$ international congress on irrigation and drainage. Beijing china 2005 Vol. 1A; improving water and land management for increasing efficiency in irrigated agriculture; 2005; P1.04.3 ref 